\title{
Seize the Day: An Existentialist Look
}

\author{
Hong $\mathrm{Wu}$ \\ Sichuan Agricultural University, Chengdu, China
}

\begin{abstract}
Saul Bellow literarily expounds in Seize the Day the existentialist propositions of Sartre, such as forlornness, freedom, individual choice, anguish and death. He exposes in the novel the living condition and the psyche of modern man through the exploration of the Protagonist's inner world. He echoes with Sartre's existentialist spirit - to be, which is of positive significance for man to live in an absurd world.
\end{abstract}

Index Terms - Bellow, Sartre, forlornness, death, self and choice

\section{INTRODUCTION}

Seize the Day was written by Saul Bellow in 1956. Coincidentally this year also witnessed the publication of Being and Nothingness, an influential yet abstruse book, written by Jean-Paul Sartre, the greatest existentialist philosopher, novelist and playwright. This event partially demonstrated the popularity of existentialism in America in 1950s. Centering its stage in Germany and France, existentialism had its earlier but insignificant transmit in America in 1930s, but mostly confining to philosophical research. After the World War II, the psychological trauma, material difficulty in reconstruction, and political intension caused by Mycoses produced a congenial land for flowering of existentialism in America. The philosophers in Germany and France were delighted in securing a place as professors or scholars in American universities or research institutes and seeing their books dealing with such occult and yet pivotal themes in existentialism as death, anxiety, and despair published edition by edition. The obvious acceptance of existentialism is present in Saul Bellow's characterization of his protagonists in The Adventures of Augie March (1953), Dangling Man (1944), The Victims, Herzog (1964), and Seize the Day (1956), nevertheless it will elicit objection from other commentators and even Saul Bellow himself to simply label him as an existentialist writer by ignoring the profundity and plurality of Saul Bellow. As a Jew who writes in English, but an American writer - a western writer who happens to be Jewish, Saul Bellow is widely believed to have achieved profundity while fixing upon a few basic ideas. The memorable thing about his novels is "not the action they detail but the thought they generate" (Shechner, 2003, p. 4). His speculative ideas conveyed in all the novels inevitably take on the print of currently popular existentialism. Seize the Day possibly best represents his understanding of life, human nature, and individuality from the perspective of existentialism. Similarly, if we say that Seize the Day is the literary interpretation of existentialism, we will depreciate the immensity and complexity of existentialism, but in it we can find many congruities and hear the identical voices of two great thinkers, Saul Bellow and Jean-Paul Sartre.

Seize the Day is a simple-plot story of a middle-aged man, Wilhelm. With the narrative technique of stream of consciousness, Bellow recounts how Wilhelm spends his devastating day from the early morning to afternoon and explores the working of his inner world at the moment when encountering unfair and cold treatment from his father, Dr. Adler and the fraud of surrogate father, Tamkin. The efforts of this paper are concentrated on Bellow's literary interpretation of man's absurd existence and its correspondent emotional response-desperation, anguish, forlornness, regret—such negative aspects of human experiences as metaphysically defined by Sartre. At the same time, some endeavor is allotted on Saul Bellow's approach to self and free individual choice during Wilhelm's life trail, spanning from the youth to his forties. At last, this paper deals with how Saul Bellow symbolically treats death to illuminate and echo with the core of Sartre's philosophy - to exist.

\section{FORLORNNESS}

Alienation has formed the spirit of modern literature which depicts the world as a wasteland, replete with coldness, haze, darkness, sterility, despair, loneliness, and deprived of hope, sunshine, friendship, warmth and comfort. As a modernist writer, Bellow unavoidably explores the alienation of human beings in his works. Wilhelm, in Seize the Day, is so alienated from his wife, Margaret, his two children, his surrogate father, Tamkin, and his own father, Dr. Adler that he has nowhere to live but to share the same roof with his father in a hotel, Gloriana, where he finds himself out of place. Dr. Adler, a successful retired internal doctor, believes that "I'm still alive, not dead. I am still here. Life isn't over yet. I am much alive as you or anyone. And I want nobody on my back" (Bellow, 1956, p. 55). He is stingy not only with money, which can help his son out of his financial collapse, but with a sympathetic word, which can meet his yearning for being "any part" of him. Tamkin, namely implying the kin of Tom, on whom Wilhelm pins great hope and doubt as well, disappears at the time of the sharp slump of lard and rye in the commodity market where they are equal partners, but Tamkin only contributes 300 dollars and Wilhelm, 700 dollars. The only connection between Margaret and Wilhelm is money, which is also the reason why Margaret refuses to give a legal divorce to Wilhelm so that he can 
marry Olive. In Wilhelm's eyes, Margaret is doing nothing but try to put an end to him. When he moves out the home with nothing, she denies his plea to have the companionship of his pet dog; when he owns no penny to himself and pleads her to be kind to him to extend the check, to go out working and not to be on his back, she hangs up the telephone with her firmly relentlessness. This gesture of hanging up the telephone symbolically severs Wilhelm completely from the world, where "every other man spoke a language entirely his own, which he had figured out by private thinking... You were lucky even then to make yourself understood. And this happened over and over and over with everyone you met. You had to translate, explain and explain, back and forth, and it was the punishment of hell itself not to understand or be understood, not to know the crazy from the sane, the wise from the fools, the young from the old or the sick from the well. The fathers were no fathers and the sons no sons. You had to talk with yourself in the daytime and reason with yourself at night". (Bellow, 1956, p. 83) This is a world of the Tower of Babel, totally incommunicable, bristling with the "otherness", so solitude is the only refuge Wilhelm can find.

Forlornness, the synonym of alienation in existentialism, is the consequence of that "God does not exist and that we have to face all the consequences of this" (Sartre, 1996, p. 668). The precursor of existentialist, Dostoevsky, says if God didn't exist, everything would be possible. That is the very starting point of existentialism. "Indeed, everything is permissible if God does not exist, and as a result man is forlorn, because neither within him nor without does he find anything to cling to and all possibility of finding values in a heaven of ideas disappears along with Him" (Sartre, 1996, p. 669). Wilhelm is forlorn, because he has turned against his God, and God has become a convenient instrument to adjust his momentary feelings: he paid a man to say a prayer for his mother at the cemetery; He didn't go the synagogue but he would occasionally perform certain devotions, according to his feelings (Bellow, 1956, p.86).

For a Jew, the faith in God and the belief in Judaism are of tremendous significance for his orientation in life and the sense of belonging in a society. Judaism has welded together homeless Jews all over the world, has provided courage and comfort for Jews to undergo numerous traumatic afflictions in thousands of years. A Jew without God in his heart is destined to drift like rootless duckweed in the river of life. Wilhelm does not choose God as his companion but money to give him direction. "They adore money, Holy money! Beautiful money! ... While if you don't have it you were a dummy, a dummy! You have to excuse yourself from the face of the earth," (Bellow, 1956, p.30) ponders Wilhelm during the breakfast conversation with his father and Mr. Pearls. This speculation reveals his indignation for average people's attitude towards money worship, but he himself consciously accepts it as a criterion to assess his self-worth, too. When the tissue of his life is dissected, the lust for the possession of money, the desire for the success of American Dream is found to be replete, wane and finally dwindle away. At the age of twenty, he changed his name from Wilky Adler to Tommy Wilhelm, a name signifying the person he dreams of becoming. He thereby recalls James Gatsby — who by calling himself Jay Gatsby thinks he can conjure up the man that Daisy Buchanan will find irresistible. Wilhelm feels that everyone is supposed to have money, and the conversations with Dr. Tamkin strengthen his belief that with just a modest amount of will and talent, he could rid himself of financial worry and distinguish himself. With the belief that he will one day become the person his name represents, he clings to the hope that easy money awaits him and imagines that his father will accept him if he has more money. Of course, this money is not in his pocket, nor in his own father who is too miserly and too self-concerned to dispense a little to him. It exists only in his long-cherished hope and in his fancied though capricious tomorrow. That's why when the hope of gaining some money is shattered with the falling of lard price in the commodity market, he is drained empty and becomes directionless, powerless and helpless. Tears of anguish and frustration give him good resort to release his pent-up desperation. This last scene of Seize the Day resembles much what happens in "the Egg", a short story by Sherwood Anderson. The father driven by American dream also cries out like a baby in the mother's arms after he fails to entertain the young customer and worsely splashes the egg on his body.

\section{SELF AND FREE CHOICE}

WILHELM IS A TYPICAL MAN DESCRIBED BY SARTRE "WHO HURLS HIMSELF TOWARD A FUTURE and who is aware of imagining himself as being in the future" (1996, p.666). His wife, Margaret, whom Wilhelm desperately wants to divorce and wants least to see, is ironically aware of this characteristic of him. She, in an unbending voice, disclosed her finding to him - "You still think like a youngster. But you can't do that any more. Every other day you want to make a new start". (Bellow, 1956, p.78) It's true that Wilhelm fancies that he is another person of tomorrow. His failure lies in the fact that he doesn't recognize there is distance between "he" and "himself" as well as "he" and "the others". What he endeavored to construct in his life is not his "real soul" but "a pretender soul" according to Tamkin's soul theory. Then what is his real soul or real en-soi ${ }^{1}$ ? The teaching of Socrates about two thousand years ago- to know thyself -is still a great issue for him.

It seems that we are falling into one of the common themes of American canons - the loss, search and reconstruction of self. But Saul Bellow reveals a self complying with Sartre's definition and uses Sartre's idea of existence to secure a place for Wilhelm's self. Sartre says "existence precedes essence" and "Man is nothing else but what he makes of himself" (1996, p. 667). It consists of two dimensions of man: the past and the future of man. As for the future it means man will be what he will have planed to be. When studying the plans Wilhelm made for himself in his life, we will find

${ }^{1}$ en-soi and pour-soi are French words used by Sartre to signify two aspects of self. 
that these fancy plans bring him nothing but the defeat in practice. Dreaming to be an actor in Hollywood at 22, he met a false broker and had an obscure experience; hoping to earn a little sum of money in the commodity market in his forties, he lost all he had. If these events compose of his plans for future at some relevant periods, they also signify his past if viewed at on this fatal day. Sartre says: "my past is my essence" (1996, p. 667). On the way toward death, man bit by bit throws after his back the past. As long as life continues, man will repeatedly be his past, the totality of his past (Du, 2002, p. 55). This is why Tommy sees himself as a hippopotamus, the carrier of a load which was his own self...In any moment of quiet, when sheer fatigue prevented him from struggling, he was apt to feel this mysterious weight, this growth or collection of nameless things which it was the business of his life to carry about. That must be what a man was for (Bellow, 1956, p.39). The burden weighing down on him is nothing but his own ego, the accumulation of his past.

His past is nothing else than "the ensemble of his acts" and choices in the acts because "an individual chooses and makes himself" (Sartre, 1996, p.673). Choice and freedom is one of important proposition of existentialism. "Freedom is the only base of value", says Sartre, "man is free in anywhere and at anytime." (1996, p.673) A free act is inevitably an act to choose a concrete thing. (Wale, 1989, p.90) Wilhelm is a man who embraces this belief and defines his self with this belief from the moment when he quarreled with his parents and sister that he would drop the university and wanted to be an actor in Hollywood twenty five years ago. He chose not to follow his father's suit to be an internal doctor; He chose to make a living as a frivolous actor in Hollywood for seven years though Venice, the broker of Hollywood hinted at the test of screen showing that he was not fit for stardom; He chose to be Tommy Wilhelm because "he can't change his lungs, or nerves, or constitution or temperament. They are not under his control. When he's young and strong and impulsive and dissatisfied with the way things are. He wants to rearrange them to assert his freedom." (Bellow, 1956, 24) Thus to be Tommy is to be the freedom of the person, escaping the deposited. Nevertheless at the age of his forties with two sons bearing his name, he feels troubled, humiliated, and regretful at this kind of freed choice. He believes that he must pay the price for it. This is the very source of his despair or bitterness as expressed by Sartre-despair is the attitude when man faces their freedom (Xu, 1988, p. 437). Now he recognizes that "Ten such decisions made up the history of his life. He had made up his mind not to marry his wife, but ran off and got married. He has resolved not to invest money with Tamkin, and then had given him a check." This self-recognition reveals that his individual freedom from the very beginning of his youth is formless and directionless.

Though emphasizing the significance of free individual choice in man's existence, which is enumerated in Sartre's assertion-I am creating a certain image of man of my own choosing, existentialists know that the choices in one's life are not easily made, but man has to make decisions. Sartre says "This is the situation and the fate of man, but one thing is necessary, that is to make a decision. The decision is fulfilled in anguish and anxiety". (Sartre, 1996, p.672) Wilhelm's conscientious yet muddle-headed choices in his life fully exemplify existentialist description of choice, especially when he is facing Tamkin.

Wilhelm regrets his past and thinks that "maybe the making of mistakes express the very purpose of his life and the essence of his being there". (Bellow, 1956, p. 57) Without his past to lie on, a person has to grasp something to sustain his life otherwise he will become a dangling man with dead past and somber tomorrow. "I admit I made many mistakes. Like I thought I shouldn't do things you had done already. Study chemistry. You had done it already. It was in the family....It's true the movies was a false step" (Bellow, 1956, p. 51), he confesses to his old Daddy but it doesn't move him. The last straw to attain father-like counsel or child-like assurance and financial assistance as well falls on Tamkin, the surrogate father. He looks on Tamkin as the person who can blaze a path for him in the jungle of life. Though having hope on Tamkin, Wilhelm still suffers between belief and disbelief when being with him. The common sense requires him to suspect Tamkin, especially his made-up life stories, but he self-deceptively and eagerly tells himself to make a decision to trust him unconditionally. The more anxiously he wants to jump out of the structure of not knowing what it is and what it is not by self-deceit, the more likely he plunges into great trouble when the beginning of the world reveals itself. This is a process full of anguish, self-torture, and self-negation. Kierkegaard, the precursor of existentialism, calls it the anguish of Abraham, i.e., the anguish of choice. You know the story: an angel has ordered Abraham to sacrifice his son; if it really were an angel who has come and said, "You are Abraham, you shall sacrifice your son," everything would be all right. But everyone might first wonder, "Is it really an angel, and am I really Abraham? What proof do I have?" In Wilhelm's case, is Tamkin really what he himself claims to be? Can he really rely on him to earn money? Especially can he really be his psychological father? At the moment, Tamkin tries to disperse Wilhelm's worries about lard price with evasive confidence and deliberate inquiry why he appears angry,

Abraham's anguish effects on him:

This was the moment to take a new look at Tamkin, and he viewed him closely but gained nothing by the new effort. It was conceivable that Tamkin was everything that he claimed to be and all the gossip false. But was he a scientific man, or not? If he was not, this might be a case for the district attorney's office to investigate. Was he a liar? That was a delicate question. Even a liar might be trustworthy in some ways. Could he trust Tamkin? Could he? He feverishly, fruitlessly sought an answer.

But the time for this question was past, and he has to trust him now. After a long struggle to come to a decision, he had given him the money. Practical judgment was in abeyance. He had worn himself out, and the decision was no decision. How had this happened? But how had this Hollywood career begun? It was not because of Maurice Venice, 
who turned out to be a pimp. It was because Wilhelm himself was ripe for the mistake. His marriage, too, had been like that. Through such decisions somehow his life had taken form. (Bellow, 1956, p. 63)

In fact such anguish and anxiety of choice accompany his whole life in which a number of possibilities are terminated as he makes the decision. But can the chosen possibility really justify the value of itself when it is regarded as valuable? Tamkin surely and finally disappoints him in the same way as other numerous choices which constitute his self and existence. They bring him nothing but anguish and frustration.

\section{ANGUISH AND DEATH}

Sartre flagrantly proclaims that man is anguish. Saul Bellow in Seize the Day also wants to depict a man of bitterness in this one-day story. The text itself is sodden with misery, which permeates between lines. Wilhelm's anguish goes along with his forlornness, stems from his past, and claims it self in his free choice, comforts a lost self and culminates in the futility of seeking a father. In the novella, there are many subtle and minute descriptions of how Wilhelm bathes himself in misery. Wilhelm, like many existentialist heroes in modern literature, has "sensitive feelings, a soft heart, a brooding nature, a tendency to be confused under pressure" (Bellow, 1956, p. 25), which he himself is aware of and so is his father, therefore he responds to his bitterness in a more drastic and intensive way. He is apt to lose control of himself in conversation with his father, and a trifle thing will elicit vehement emotions and sentiments. The breakfast with his father in the dining hall in Gloriana reveals it. His father's observance on Tamkin's incredibility makes him profoundly bitter that his father should speak to him with such detachment about his welfare. His father's detachment is a great grief and too much to bear for him. His father's advise "You make too much of your problem. They ought not to be turned into a career" takes him great efforts to restrain himself from being in gloom and anger. Rehearsing what Margaret has done to him before his father reinforces his misery and he chokes himself until nearly losing his breath as if he is going to die. His father's reprimand of his tolerance to Margaret's unreasonable treatment makes tears approach his eyes but he doesn't let them out. His father's firm and callous refusal to give him any money throws him into the abyss of despair and humiliation- "He could not get out of the sharply brilliant dining room fast enough. He was horribly worked up; his neck and shoulders, his entire chest ached as though they had been tightly tied with ropes. He smelled the salt odor of tears in his nose". (Bellow, 1956, p.80) His consciousness of the purpose of life- "to carry his peculiar burden, to feel shame and impotence, to taste these quelled tears" - echoes with Sartre's proclamation-man is anguish. He has married to suffering as Tamkin puts it. Tamkin's therapy of here-and-now doesn't work on him. He only hears the poem Margaret read for him many years ago:

Come then, sorrow!

Sweet sorrow?

Like an own babe I nurse thee on my breast!

Come, the Sorrow!

I thought to leave thee,

And deceive thee,

But now of all the world I love thee best. (Bellow, 1956, p. 89)

When his father knows Wilhelm lost all the money, he demands Wilhelm to go away and calls him a slob. At that moment Wilhelm even has no energy and courage to lose his temper with his old father but to surrender helplessly to infinite misery.

Camus believes that suicide is the natural response to absurdity and he even asserts in Sisyphus that suicide is the only issue in philosophical thinking. If built-up misery of one person can't get vent to release itself, he will reach the pinnacle of bitterness, i.e., death. The agony enshrouds Wilhelm bit by bit; simultaneously the idea of death brews, merges, grows, and finally takes shape. When his father suggests that Margaret is the beneficiary of his children's insurance policy, Wilhelm unconsciously mentions the death "Let her be. I'd sooner die myself before I collected a cent of such money" (Bellow, 1956, p. 46). He repeatedly says that Margaret wants to strangle him; actually he is hinting subliminally at himself that he shall die. His father's words give him the impression that he should leave the world first. He dislikes Mr. Rappaport, because, on one hand Mr. Rappaport is an old rich miserly man, on the other, his chicken business reminds him of death of numerous slaughtered chickens. He often visits the cemetery where his mother is buried. The bad maintenance of the grave makes him think of having himself being cremated. He finds a strange uneasiness tore at his body while Tamkin compares the commodity market to killing, as if he is being killed. Eventually all these miseries drive Wilhelm to drown himself in tears at a stranger's funeral. The scene is like what he imagined when passing the pool in Gloriana: The flowers and lights fused ecstatically in Wilhelm's blind, wet eyes; the heavy sea-like music came up to his ears. It poured into him where he had hidden himself in the center of a crowd by the great and happy oblivion of tears. He heard it and sank deeper that sorrow, through torn sobs and cries toward the consummation of his heart's ultimate need. (Bellow, 1956, p.118)

In the congress library address, Bellow deplores the fact that in his recent fictions the self is asked to prepare itself for sacrifice.... (Clayton, 1979, p.115) Therefore the stranger's funeral can be symbolically taken as Wilhelm's. The corpse lies in the coffin is his past, or his self, the presentation soul, the impostor soul, the pretender soul as being put by Tamkin that "in the human bosom there isn't just one soul. There are a lot of souls. But there are two main ones, the 
real soul and a pretender soul.... The true soul loves the truth. And, when the true soul feels like this, it wants to kill the pretender. The love has turned into hate. Then you become dangerous. A killer. You have to kill the deceiver". (Bellow, 1956, p. 70-71) Tamkin's soul theory in the essence is a parody of Sartre's self concept. Sartre divides self into two parts, one, "pour-soi" and the other, "en-soi". Existence is "en-soi", which fills up the self, or in other words existence doesn't have any correlation with self because it is self. (Xu, 1988, p. 34) In this battle, pretender soul is killed and survives surely the real soul. Only after burying the impostor self can real soul regain strength to face the terror of pure being and the terror of his own being, and only thus can Wilhelm find the place for his real soul to perch. This place is existence. Only at this moment Wilhelm is himself, because he is there. Saul Bellow symbolically adopts death as a means for Wilhelm to find out the truth of existence - to live in here-and-now, which is implied in the title Seize the Day and which is didactically and hypnotically instilled by Tamkin. In this sense, Tamkin, like a charlatan guru, conveys what Saul Bellow wants to say to Wilhelm. Though his message is not complete and sometimes false, his hypnotic preaching and exotic thoughts are effective in some degree to lead Wilhelm to dissect his self, to go out of his own small circle, and to plunge into pure existence. He is like a catalytic that causes and accelerates Wilhelm's death and rebirth. The end of story resembles a lot Nausea by Sartre. In Nausea Roquentin gives up the illusion of a fixed ego and submits instead to existence, an existence as free and superfluous as that of a tree. But "this freedom,' says Roquentin, "is rather like death" (Clayton, 1979, p.209). And he plans to "outlive himself" (Clayton, 1979, p.204) simply to exist (Clayton, 1979, p. 115). Of course, the last scene in the novella also can be interpreted as that Wilhelm outlives in tears, humiliation, misery, regret, despair, and return to the reality after his hope and expectation of two fathers are shattered. The event of loss of all his money in the commodity market prompts him to understand that reality alone is what counts, and that dreams, expectations, and hopes warrant no more than to define a man as a disappointed dream, as miscarried hopes, as vain expectations. The reality is life and existence. This interpretation still can find the path to the essential of Sartre's philosophy and the pith of whole existentialism.

\section{CONCLUSION}

In Seize the Day, Saul Bellow sketches an alienated person, Wilhelm, and exposes to us how a tortured soul grapples with his humiliating past itching in a youth belief in individual freedom, how a crippled son oscillates between two fathers, a real one and a substitute one, how an illusioned American Jew wrestles with money, yet at the brim of destruction simply survives when all his sobs, regrets, despair, and anguish melt in tears. Problems remain there, no matter whether soluble or insoluble, because life is like that - being bristling with problems at any time and any place. There is no easy and permanent resolution to life's problems which are intrinsically complicated and illogical, and further compounded by the absurdity and chaos of the modern world. Seize the Day fully illustrates the recurrent practice of Saul Bellow in his literary creation - he does not avoid conditions of alienation and despair; but he insists that through them the power of the imagination should reveal the greatness of man and that we are not gods, not beasts, but savages of somewhat damaged but not extinguished nobility (Clayton, 1979, p.132). It is a belief of optimism in pessimism. After that doom day, Wilhelm will continue making free choices and defining himself by his series of acts. It is hinted that he will move out of New York to live in Roxbury, like Herzog's choice to live in the countryside, and will make up with Olive in the future. This kind of optimism in pessimism is true with Sartre. Being and Nothingness is devoted to explicating this point - man is not an entity, but an awareness, so he is destined to go outward, destined to make free choices of their action, thus existence is meaningful (Du, 2002, p.2). Seize the Day metaphorically and rhetorically paraphrases what Sartre presents in esoteric philosophy about such propositions as anguish, despair, freedom, individual choice, self, and existence. Sartre says that existentialism has an optimistic toughness and it isn't trying to plunge man into despair at all, whereas it is a philosophy that makes life possible. Sartre and Saul Bellow both have defended man's dignity and found a way for people to endure and prevail in a special historical period. Their contribution for human beings' understanding of life and self has gained the recognition and the world by the Nobel Prize.

\section{REFERENCES}

[1] Bellow, Saul (1956). Seize the Day. New York: the Penguin Press.

[2] Clayton, Jacob John. (1979). Saul Bellow: in Defense of Man. $2^{\text {nd }}$. London Bloomington: Indiana University Press.

[3] Sartre, Jean-Paul. (1996). Existentialism. In Linda H. Peterson \& John C. Brereton (eds.). The Norton Reader: An Anthology of Nonfiction Prose. New York: W. W. Norton \& company, Inc, 666-674.

[4] Shechner, Mark. (2003). American-Jewish Literature. In Sorrel Kerbel (ed.). The Jewish Writers of the 20 th Century. NY: Fitzroy Dearborn, an imprint of the Taylor and Francis Group.

[5] Kauffman, W. (1987). Chen Guying (trans.). Existentialism: from Dostoevsky to Sartre. Beijing: Commercial Publishing House.

[6] Xu Chongwen (ed.) (1988). Existentialism. Beijing: China Social Science.

[7] Wale, Jean. (1987). Weng Shaojun (trans.). Existentialism. Shanghai: The Joint Publishing Company Ltd., 1987.

[8] Du Xiaozhen. (2002). The Burden of Existence and Freedom: Approaching Sartre's Being and Nothingness. Shandong: People's Publishing House. 
Hong Wu, born in 1975, Sichuan province, China, is currently a lecturer of English at Sichuan Agricultural University, Chengdu, China. She earned her master's degree in English Language and Literature from Sichuan Normal University, China, in 2006. Her research interests cover such areas as contemporary American literature, and esp., African American literature. 